\title{
E-læring - hvad \\ med juraen?
}

- Oplæg på

Forskningsnetkonference 2008

\section{Morten Rosenmeier}

Lektor, ph.d., KU, formand for Udvalget til

Beskyttelse af Videnskabeligt Arbejde (UBVA)

Morten Rosenmeier er lektor i immaterialret ved Det Juridiske Fakultet, KU, og formand for UBVA. Han har skrevet forskellige bøger om ophavsret mv. Man kan se mere om ham på hans hjemmeside:

www.jur.ku.dk/mortenrosenmeier. 


\section{Forskningsnettet og UBVA}

Udvalget til Beskyttelse af Videnskabeligt Arbejde (UBVA) er et udvalg under Akademikernes Centralorganisation, der varetager akademikeres interesser, når det kommer til »immaterialret«, dvs. ophavsret og patentret m.m. UBVA rådgiver bl.a. undervisere på universiteter, gymnasier og andre læreanstalter, og de AC-organisationer, de er medlem af, når de har ophavsretlige problemer. Vi har en hjemmeside med information om ophavsret på www.ubva.dk, hvor der bl.a. ligger artikler om ophavsret, patentret m.m.

Vi har et tæt samarbejde med Forskningsnettet, når det kommer til at rådgive om de juridiske aspekter i forbindelse med e-læring. På de fleste universiteter og andre højere læreanstalter går man mere og mere over til det, bl.a. ved at underviserne lægger digitalt undervisningsmateriale ud på holdenes intranetsider. Hvis en læreanstalt er rigtig fremme i skoene, kan det være, at man ligefrem webcaster undervisningen, dvs. optager den og lægger den ud på inter- eller intranet. Spørgsmålet er imidlertid, om juraen sætter grænser for, hvad man må, når det handler om e-læring. Det er også et spørgsmål, i hvilket omfang man som underviser skal acceptere, at ens undervisningsinstitution optager ens undervisning og webcaster den.

UBVA og Forskningsnettet holder bl.a. fælles gå-hjem-møder på universiteter og andre læreanstalter, der har lyst til at få besøg af os. I 2008 har vi desuden lavet en stor fælles hjemmeside, der hedder »E-læring og jura «. Den indeholder både artikler, en e-bog, der hedder Ophavsret for begyndere, film, tegnefilm, en quiz m.m. Desuden er der en blog, hvor man kan få svar på spørgsmål om ophavsret.

Siden ligger på www.forskningsnettet.dk/jura, og vi har allerede haft ca. 80.000 hits på den. Det er vores mål, at der på sigt skal være links til siden fra alle danske uddannelsesinstitutioner.

Jeg vil i denne artikel prøve skitsere, hvad de juridiske regler om e-læring går ud på. Hvis man gerne vil mere til bunds i tingene, kan man se mere på www.forskningsnettet.dk/jura.

\section{Det kræver normalt tilladelse at lægge}

\section{undervisningsmateriale på nettet}

Når Forskningsnettet og UBVA er ude at holde gå-hjem-møder, er der altid nogen, der rækker hånden op og spørger, om ikke det er rigtigt, at man gerne må lægge alt det, man har lyst til, ud på nettet, så længe det bare sker på lukkede intranetsider, som der ikke er offentlig adgang til. Så svarer vi, at det er forkert, og så ser folk meget forargede ud. 
Sådan er det imidlertid nu engang. Undervisningsmateriale - artikler, boguddrag, fotografier, grafik, tabeller m.m. - er normalt beskyttet af ophavsretsloven. Det betyder, at man normalt ikke må lægge materialet ud på inter- eller intranet, medmindre man har fået lov. Det er lige meget i den forbindelse, om man kun lægger materialet ud i lukkede grupperum.

Der er dog nogle tilfælde, hvor man ikke behøver spørge om lov. De vigtigste er:

- Hvis man har lavet materialet helt selv, og det ikke er udgivet på et forlag el.lign., kan man gøre med det, hvad man vil, herunder lægge det på nettet.

- Man må bruge billeder af bygninger uden tilladelse. Det står i ophavsretslovens $\S 24$, stk. 3.

- Man må gerne bruge billeder af skulpturer, statuer og anden billedkunst, der er varigt anbragt på/ved offentlige pladser og veje, hvis ens undervisning ikke er »erhvervsmæssig «. Det er normal universitets- og gymnasieundervisning ikke. Reglen står i ophavsretslovens $\S 23$, stk. 2.

- Hvis ens uddannelsesinstitution har en Copydan-aftale, må man bruge værker på den måde, der står i aftalen. Se mere om Copydan på www.copydan.dk.

- Man må altid gerne citere fra andres værker, dvs. låne ganske små beskedne bidder fra dem og bruge dem i sine egne værker. Der er kun tale om lovligt citat, hvis det, man låner, kun fylder en lille smule, både i det værk, citatet tages fra, og i den sammenhæng, man selv vil bruge det i. Desuden skal det fremgå klart, hvad der citeres, f.eks. vha. kursivering eller anførelsestegn. Endelig skal man komme med en udtrykkelig og præcis kildehenvisning. Brug af stillbilleder fra film og tvudsendelser kan ikke være citat.

Hertil kommer forskellige andre undtagelser, som man kan se, høre og læse mere om på E-læring og jura-siden.

\section{Må man linke til beskyttet materiale som led i}

\section{e-læring?}

Man må altså ikke lægge beskyttet materiale på nettet bortset fra i visse tilfælde. Et andet spørgsmål er, om man må linke til beskyttet materiale i elæringssammenhæng, og om man f.eks. må skrive i et grupperum, at de studerende til næste gang skal læse den og den artikel, og så indsætte et link til artiklen. 
Indtil der bliver afsagt nogle flere domme, er det desværre juridisk tvivlsomt, i hvilket omfang man må linke på nettet. Der er dog visse ting, der ligger ret fast, og det har vi mere om på hjemmesiden.

\section{Hvad med webcast af undervisning?}

I gamle dage foregik undervisning ved hjælp af tavle og kridt, og hvis de studerende ikke mødte op til timerne, var det bare ærgerligt. I dag kan man imidlertid webcaste undervisning, og der er vist mange politikere m.fl., der forestiller sig, at al universitetsundervisning med tiden skal optages og lægges på nettet som led i »open access«. Nogle steder har man ladet sig i den grad rive med af stemningen, at man har sat kameraer op i undervisningslokalerne uden at orientere underviserne først. Det har underviserne ikke altid været lige glade for, for selvom webcast er et spændende tilbud, er det ikke al undervisning, der egner sig lige godt til det. Webcast kan i øvrigt somme tider påvirke undervisningen i negativ retning, fordi tanken om, at alting optages, får både underviseren og de studerende til at lægge bånd på sig selv. Det er også et relevant spørgsmål, hvordan man som underviser er stillet, hvis man efterfølgende får et ønske om, at en optagelse skal fjernes fra nettet igen.

Rent juridisk betyder ophavsretsloven og persondataloven imidlertid, at man som underviser ikke har pligt til at acceptere, at uddannelsesinstitutionerne webcaster undervisningen, uden at spørge én først. Underviseren kan desuden altid komme efterfølgende og forlange, at optagelserne fjernes igen. Se mere på siden om E-læring og jura.

UBVA har lavet nogle forslag til, hvordan vi mener aftaler om webcast, indgået mellem læreanstalter og undervisere, bør se ud. Dem kan man også downloade.

Det kan med andre ord kun gå for langsomt med at få besøgt hjemmesiden: www.forskningsnettet.dk/jura 